\title{
Modeling Switching Behaviour of Direct Selling Customers
}

\section{P Msweli-Mbanga}

School of Economics and Management, University of KwaZulu-Natal

\section{ABSTRACT}

The direct selling industry suffers a high turnover rate of salespeople, resulting in high costs of training new salespeople. Further costs are incurred when broken relationships with customers cause them to switch from one product supplier to another. This study identifies twelve factors that drive the switching behaviour of direct sales customers and examines the extent to which these factors influence switching. Exploratory factor analysis was used to assess the validity of these factors. The factors were represented in a model that posits that an interpersonal relationship between a direct sales person and a customer moderates the relationship between switching behaviour and loyalty. Structural equation modeling was used to test the proposed model. The author then discusses the empirical findings and their managerial implications, providing further avenues for research.

JEL M31

\section{INTRODUCTION}

Despite being the oldest method of marketing, relatively little is known about the direct selling industry, direct selling companies, direct selling salespeople and consumers who buy from direct sellers. According to Peterson and Wotruba (1996) this lack of knowledge is due to a number of factors ranging from the 'invisible' nature of direct selling and the fact that the majority of direct selling firms are privately held and relatively small. Governmental reporting requirements are few and the companies are generally reluctant to release information about themselves. Nevertheless, the industry is quite sizeable with a global annual revenue of $\$ 85$ billion dollars (World Federation of the Direct Selling Association, 2001). In South Africa the industry generates a turnover of approximately R2 billion annually, forty percent of which is consumed by the sales force and their families (Ryan, 2002).

It is estimated that there are almost 36 million individuals involved in direct selling worldwide (World Federation of Direct Selling Associations, 2001). 
These people are usually referred to as distributors or independent contractors and they operate from their home base, and selling consumer goods or services to consumers outside retail outlets. Every distributor is essentially an entrepreneur running a small business under the direction of the founding leader.

Direct selling is a nonstore approach to retailing. It is a marketing activity involving face-to-face contact between customer and salesperson in a location other than a retail store. Direct selling is unique in that the salesperson is the exclusive interface between the firm and the customer (Lambert, Sharma \& Levy, 1997). The personal contact between a salesperson and a customer in the direct selling context highlights the importance of the salesperson and his/her role, not only in the distribution channel, but also in maintaining relationships with customers.

There are two types of direct selling organisations: (1) single level organisations and (2) multilevel organisations. In the case of single level organisations, a distributor is recruited and trained to sell a range of products offered by the organisation at a discounted price. Distributors then make retail profit when they sell to their customers. In multilevel organisations, distributors generate income, not only from their personal sales, but also from commissions and bonuses based on the sales of those whom they may recruit directly or indirectly into their networks. The sales support functions of training, motivation, administration and delivery of goods are the responsibilities of distributors in the case of multilevel direct selling organisations.

A number of advantages are cited for selling products through the direct selling channel of distribution. These include an increased ability to secure distribution and sales quickly at a low level of fixed cost (Clothier, 1994), and the ability to gain entrance to a market, while avoiding excessive promotional and advertising expenses. While there are positive aspects of direct selling, there are negative aspects as well. There is evidence in literature for instance, that the direct selling industry suffers very low rates of distributor retention (Tyagi \& Wotruba, 1993; Bloch, 1996; Berry, 1997). The low retention rate in the industry results in high costs associated with engaging new salespeople, and significant costs arising from broken relationships with customers. The broken relationships with customers lead to not only the spread of negative word-of-mouth, but to frequent switching from one product supplier to another.

This study seeks to examine the switching behaviour of direct sales customers. There are very few studies that have addressed switching behaviour in the retail sector. Keaveney (1995) points out that the reasons for switching services would differ from the reasons for switching retail goods. This study thus seeks 
to examine why retail customers switch suppliers. Specifically, this study identifies the factors that lead to switching behaviour in customers who purchase directly sold goods and the extent to which these factors influence switching. An understanding of the switching behaviour of direct sales customers will be useful to both practitioners and researchers. Practitioners will be able to devise strategies that reduce the tendency to switch, thereby retaining loyal customers. Researchers could separate those who are most likely to switch from those who are least likely to switch and study the loyalty patterns within the two groups.

\section{OBJECTIVES OF THE STUDY}

The purpose of this study is to identify the variables that drive the switching behaviour of direct sales customers. The study builds on Keaveney's (1995) research by presenting a set of variables which include and extend upon those identified by Keaveney (1995) in a parsimonious model that describes the switching behaviour of direct selling customers. The study tests a model that posits that interpersonal relationship between a direct sales person and a buyer moderates the relationship between switching behaviour and loyalty.

This study adds to the understanding of switching behaviour by:

- identifying variables that impact on the switching behaviour of direct sales customers;

- $\quad$ examining the switching behaviour-loyalty link in the direct selling context;

- $\quad$ testing whether the switching behaviour-loyalty link in the direct selling context is moderated by interpersonal relations;

- $\quad$ examining the simultaneous effect of fifteen variables in the proposed switching behaviour model.

\section{THE THEORETICAL BASE FOR THE PROPOSED MODEL}

Switching behaviour of customers has long been of interest to marketing researchers (Kuehn, 1962; Morrison, 1966; Bass, 1974) because of the link between switching behaviour and profitability. Most of the switching behaviour research between the $70 \mathrm{~s}$ and the $80 \mathrm{~s}$ tended to focus on the impact of marketing mix elements and how these contributed to the switching behaviour of customers (Chance \& French, 1972; Carpenter \& Lehmann, 1985; Guadagni \& Little, 1983; Gupta, 1988). In the 90s the switching behaviour literature was dominated by authors who linked switching behaviour to service quality and 
customer satisfaction (Keaveney, 1995; Mittal \& Lassar, 1998; de Ruyter, Wetzels, and Bloemer 1998).

In recent years there has been an ongoing debate over whether customer switching behaviour-customer satisfaction link (Ganesh, Arnold \& Reynolds, 2000) and the link between switching behaviour and perceptions of quality (Keaveney, 1995). In line with this thinking, Ganesh, Arnold \& Reynolds (2000) argue that the switching behaviour of customers may not necessarily be related to customer loyalty. This notion is further supported by Mittal and Lassar (1998) who assert that customers who report a high loyalty rating may still possess a predisposition to switch suppliers. Conversely, there are studies that suggest that loyalty is negatively related to switching behaviour (Srnivasan, 1996), and that switching occurs far less frequently in the presence of loyalty.

The reality is that loyal customers do display a predisposition to switch suppliers, and this has caused confusion in establishing an unequivocable connection between the two aspects of behaviour. Lee and Cunningham (2001) suggest that the confusion may be because the notion of switching barriers has never been considered. A switching barrier, as Lee and Cunningham (2001) explain, is determined by the degree of ease with which customers are able to change service providers. Lee and Cunningham (2001) argue that the impact of such a barrier on customer loyalty depends on the market structure and industry within which companies operate. By taking this theory into account, this study seeks to focus on creating a greater understanding of the switching behaviourloyalty link in the direct selling industry.

The representation of customer loyalty and its link to personal relations in the direct selling industry builds on two sets of empirical findings. First, Frenzen and Davis (1990) report that direct selling consumers obtain social and psychological benefits from their personal relationships with the seller. The authors propose that buyers are bound by their close interaction with the sellers, and may even go to the extent of purchasing unwanted goods, paying premium prices, or forgoing discounts in order to benefit a particular seller. Jones, Mothersbaugh and Beatty (2000) affirm this contention, although their study was based on service personnel. Jones et al. (2000) define interpersonal relationships as the strength of personal bonds that develop between customers and their service employees. In their work, Jones et al. (2000) found that interpersonal relationships and perceived switching costs have an impact on repurchase intention in the service industry. 


\section{Figure 1 Proposed switching behaviour model}

$(+)$

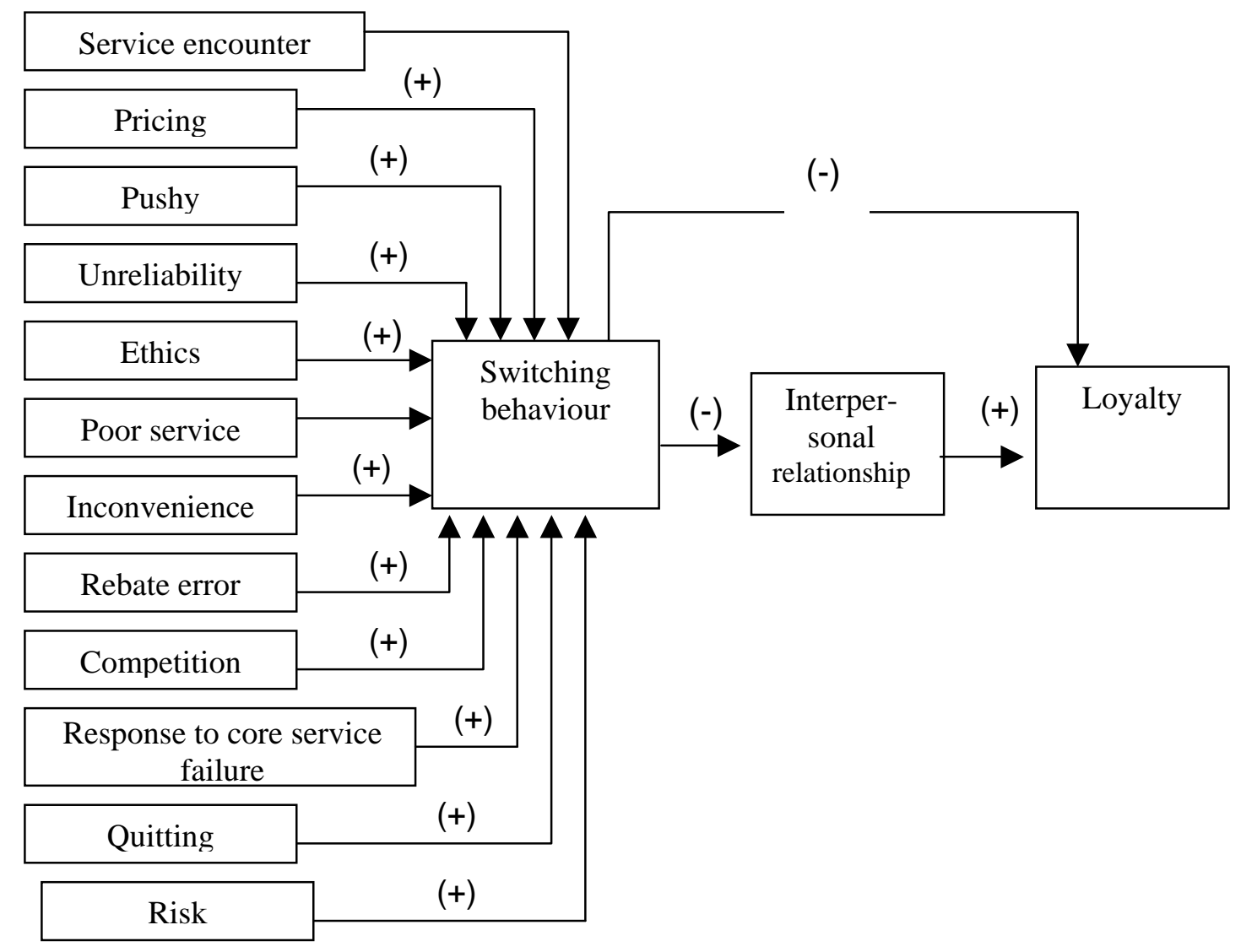


As Figure 1 illustrates, Keaveney's (1995) model was used as a base to identify the factors and descriptors of the factors that impact on the switching behaviour of direct sales people. Keaveney's (1995) research identified eight factors, namely (1) price, (2) inconvenience, (3) core service failure, (4) service encounter failures, (5) response to service failure, (6) competition, (7) ethical problems and (8) involuntary switching, explained by 27 items. This study generated 30 additional items arising from in-depth interviews with direct sales customers as discussed in the research methodology section below.

\section{RESEARCH METHODOLOGY}

\section{Research design and sampling issues}

In the initial phase of the research, in-depth interviews with direct sales customers and direct selling industry experts were conducted to tap into their insights about the factors that lead to the switching of product suppliers. A review of relevant literature identified several additional factors that could impact on switching behaviour of customers. A total of 68 items were generated from literature and the in-depth interviews. A questionnaire was developed to capture these items.

Next, the questionnaire was pilot tested on a sample of 15 customers who had purchased products from a direct selling firm. On the basis of the pretest, the questionnaire was revised and subsequently administered to a sample of direct selling customers in the KwaZulu-Natal area. Sample members had to conform to one requirement - that of having bought products from a direct selling firm in the past six months. Using a mall intercept method (Churchill, 1996), data was collected from 200 respondents. There were more respondents (39 per cent) in the age category between 31 and 40 years and more than 40 per cent of the respondents had high school education. The proportion of female respondents was slightly higher (51 per cent) compared to male ( 49 per cent) respondents, and 17 per cent of them were black, 32 per cent Indian, 34 per cent White, and 17 per cent Coloured.

\section{Measures}

Factors impacting on switching behaviour

Before the proposed switching behaviour model could be tested, the factorial validity of the 68 items identified from literature and in-depth interviews had to be tested using exploratory factor analysis. Evaluation of the Eigenvalues and screenplot indicated a twelve-factor solution which explained 74 per cent of variation in the items. The items to measure each one of the twelve factors are 
outlined in Table 1. All items were measured on a five-point Likert scale ranging from " 1 " = strongly disagree to " 5 " = strongly agree.

\section{Switching behaviour}

Switching behaviour was measured using a single item: "What are your intentions with regards to switching from your current direct selling supplier to other direct selling suppliers within the next three months?” Responses were scored on a scale of 1-3, with 1 = "definitely not switch", 2 = "might switch", and 3 = "definitely switch".

\section{Interpersonal relationship}

Interpersonal relationship was operationalised on the basis of five items developed by the authors:

(a) I have a good relationship with my direct sales person

(b) My direct sales person gives me special attention

(c) My direct sales person goes out of his way to help me

(d) I trust my direct sales person

(e) I have a long-term relationship with my direct sales person

Each of the items was measured on a five-point Likert scale ranging from ' 1 ' = strongly disagree to ' 9 ' = strongly agree.

\section{Loyalty}

The measure of store loyalty was adapted from the loyalty measure developed by Sirohi and Mc Laughlin (1998). The measure is determined by three items: (1) How likely would you be to recommend a direct seller and his/her product range to a friend or relative? (2) How likely are you to purchase from your current direct seller in the next six months? (3) How likely are you to continue purchasing your products from your direct seller? The responses were measured on five-point Likert scales, ranging from " 1 " = not at all likely to "5" extremely likely.

\section{Analytical procedure}

Initially, exploratory factor analysis was used to assess the factorial validity of the items used to develop the scale used to measure the determinants of switching behaviour. Twelve factors were identified and structural equation modelling (SEM) was used to test whether the twelve determinants of switching behaviour (as outlined in Table 1) lead to switching, as well as the extent to which these variables influenced switching. Structural equation modeling was also used to test whether interpersonal relations moderate the switching behaviour-loyalty relationship. As such, the simultaneous effect of the 15 variables as depicted in Figure 1 was tested to assess model fit. SEM is a confirmatory analytical tool, and its usefulness lies in providing estimates of the 
strength of all the hypothesised relationships as specified in the model illustrated in Figure 2.

The scores on all items for each variable were aggregated to obtain single dimension scores. The structural model was thus written as a completely endogenous model. This approach to model estimation is appropriate, given the objectives of the study: (1) to identify the variables that impact on switching behaviour and the extent to which they influence switching; (2) to evaluate the effect of variables in the hypothesised relationships as illustrated in Figure 1. Testing an endogenous model in these circumstances is advantageous and efficient because only the beta coefficients are estimated and the method does not require exogenous constructs to be nominated (Jöreskog \& Sorbom, 1996). Furthermore, a number of studies have based research conclusions on completely endogenous models (Sager \& Menon, 1994; Bagozzi, 1980; Msweli-Mbanga, 2001).

The software program AMOS was used to test the hypothesised model. As recommended by Anderson and Gerbing (1988) a two-step procedure, that separately estimates and respecifies the measurement model prior to simultaneous estimation of measurement and structural model, was followed.

\section{EMPIRICAL FINDINGS}

\section{Factor analysis results and validity of the switching behaviour determinants}

Based on the in-depth interviews in the first phase of the research as well as the literature review, 68 items that influence switching behaviour were generated. All 68 items were factor analysed using component factor analysis to examine the underlying relationships among the items and to summarise into a smaller set of factors. Although the sample size of 200 provides a case-to-variable ratio less than the minimum requirement of 1 observation to 5 responses, there are other scale developers (Parasuraman, Zeithaml \& Berry, 1988; Churchill, Ford $\&$ Walker, 1974) who have used lower case-to-variable ratios.

The factors were orthogonally rotated using the Varimax method of rotation (Norušis, 1994). According to Hair, Anderson, Tatham and Black (1998) an orthogonal factor solution is the best if the objective of research is to reduce a larger number of variables to a smaller set of uncorrelated variables for subsequent use in prediction techniques. Kaiser's criterion was used for deciding which factors to eliminate (Bryman \& Cramer, 1994). The factor solution resulted in twelve factors with Eigenvalues greater than one. The 
twelve factor solution accounted for 74 per cent of the variance. In order to purify the list, items with loadings of 0.3 and less were eliminated. Items that correlated high with more than one factor were also eliminated to ensure that true discriminant validity had been established among the constructs.

Having eliminated items from the factors, one factor (service encounter failure) still had a considerably high number of items acting as indicators for the construct. Apart from the theoretical basis that should be used to select indicators of a construct, Hair, Anderson, Tatham and Black (1998) contend that there is no upper limit in terms of the number of indicators. However, unidimensionality of the construct was checked using Cronbach alpha as suggested by Hair et al. (1998). The findings were within the bench mark of 7 indicating that the construct was unidimensional. The factor structure illustrated in Table 1 was used to construct the causal model depicted in Figure 1.

\section{Reliabilities and descriptive statistics of variables in the model}

A total of 15 variables are hypothesised to interact as depicted in Figure 2. Cronbach's alpha has been used to assess the internal consistency of the measuring scales. The Cronbach's alpha measurement is based on the average inter-item correlation, and the values range from $0-1$, with higher values indicating higher reliability among items. Table 2 shows that the internal consistency of the variables, measured by Cronbach's alpha, are within the benchmark of .70 as suggested by Nunnaly and Bernstein (1994). The single item measure of switching behaviour has been fixed to unity, because it is not empirically possible to estimate its reliability (Hair et al., 1998). While the single item measure seems to tap into the central switching behaviour construct as conceptualised by Keaveney (1995), a multiple item scale would have been preferable. However, single item measures have been used in previous studies using structural equation modeling methodology (refer to Capraro, Broniarczyk, \& Srivastava, 2003; MacKenzie, Podsakoff \& Ahearne, 1998; Hom \& Kinicki, 2001).

Assessing the internal consistency of the variables is a requirement in SEM and in theory testing (Hair et al., 1998), not only to assign meaning to the parameters that are to be estimated, but also to assess unidimensionality. Anderson and Gerbing (1988) and Hair et al. (1998), posit that unidimensionality of variables is assessed using internal consistency, and the alpha values in Table 2 illustrate that the variables are indeed, unidimensional. 
Table 1 Determinants of switching behaviour

\begin{tabular}{|c|c|c|}
\hline SEF & Service encounter failure & $\begin{array}{l}\text { Factor } \\
\text { loadings }\end{array}$ \\
\hline Factor 1 & $\begin{array}{l}\text { 1. Not helpful } \\
\text { 2. Unfriendly } \\
\text { 3. Refuse to accommodate my requests } \\
\text { 4. Neglect to answer my questions } \\
\text { 5. Impatient } \\
\text { 6. Condescending } \\
\text { 7. Ill-tempered }\end{array}$ & $\begin{array}{l}.82 \\
.78 \\
.75 \\
.80 \\
.72 \\
.75 \\
.74\end{array}$ \\
\hline $\begin{array}{l}\text { PRICE } \\
\text { Factor } 2\end{array}$ & $\begin{array}{l}\text { Pricing } \\
\text { 1. Prices too high } \\
\text { 2. Unreasonable price increases } \\
\text { 3. Prices were deceptive } \\
\text { 4. Prices charged unfair } \\
\end{array}$ & $\begin{array}{l}.82 \\
.86 \\
.74 \\
.65\end{array}$ \\
\hline $\begin{array}{l}\text { PUSHY } \\
\text { Factor } 3\end{array}$ & $\begin{array}{l}\text { Pushiness of direct seller } \\
\text { 1. Made me feel uncomfortable } \\
\text { 2. Did not have respect for my feelings } \\
\text { 3. Was over-bearing } \\
\text { 4. Employed sales tactics that were not professional }\end{array}$ & $\begin{array}{l}.56 \\
.58 \\
.50 \\
.53\end{array}$ \\
\hline $\begin{array}{l}\text { ETHICS } \\
\text { Factor } 4\end{array}$ & $\begin{array}{l}\text { Ethical behaviour of direct seller } \\
\text { 1. Engages in deceptive consumer practice } \\
\text { 2. Terms of sale are ambiguous and unclear } \\
\text { 3. Does not perform in accordance with the terms of } \\
\text { warrantees and guarantees }\end{array}$ & $\begin{array}{l}.70 \\
.76 \\
.72\end{array}$ \\
\hline $\begin{array}{l}\text { PSQ } \\
\text { Factor } 5\end{array}$ & $\begin{array}{l}\text { Poor service quality } \\
\text { 1. Wait too long to receive products ordered } \\
\text { 2. Mistakes in processing of orders } \\
\text { 3. Service quality deteriorates } \\
\text { 4. Product packaging damaged }\end{array}$ & $\begin{array}{l}.77 \\
.74 \\
.50 \\
.51\end{array}$ \\
\hline $\begin{array}{l}\text { UNREL } \\
\text { Factor } 6\end{array}$ & $\begin{array}{l}\text { Unreliability of direct seller } \\
\text { 1. Difficult to contact } \\
\text { 2. Does not respond to queries } \\
\text { 3. Does not make follow-up calls } \\
\text { 4. Does not fulfil promise to deliver products on time }\end{array}$ & $\begin{array}{l}55 \\
58 \\
53 \\
60\end{array}$ \\
\hline $\begin{array}{l}\text { RISK } \\
\text { Factor } 7\end{array}$ & $\begin{array}{l}\text { Risk } \\
\text { 1. Products might be a risk to my health } \\
\text { 2. If at risk of losing money by purchasing products that } \\
\text { might not work } \\
\text { 3. If products pose risk to my social image }\end{array}$ & $\begin{array}{l}.81 \\
.85 \\
.76\end{array}$ \\
\hline $\begin{array}{l}\text { QUIT } \\
\text { Factor } 8\end{array}$ & $\begin{array}{l}\text { Direct seller quit selling } \\
\text { 1. Direct seller quit selling } \\
\text { 2. Lost interest in selling } \\
\text { 3. Impossible to contact }\end{array}$ & $\begin{array}{l}.89 \\
.92 \\
.85\end{array}$ \\
\hline
\end{tabular}




\section{Table 1 continued}

\begin{tabular}{|l|l|c|}
\hline SEF & Service encounter failure & $\begin{array}{c}\text { Factor } \\
\text { loadings }\end{array}$ \\
\hline INC & \multicolumn{1}{|l||}{ Inconvenience } & \\
& 1. Product outlet not located closer to me & .44 \\
& 2. Hours of operation inconvenient to me & .49 \\
3. Delivery times not convenient & .52 \\
\hline REB & Rebate error & .60 \\
Factor 10 & 1. Receive incorrect rebate statements & .59 \\
& 2. Failure to correct errors in rebate statements & .57 \\
\hline RTSF & 3. Take too long to correct rebate error & .75 \\
Factor 11 & Response to service failure & .81 \\
& 1. Reluctant in responding to service problems & .69 \\
\hline COMP & 2. Fail to respond to service problems & .55 \\
Factor 12 & 3. Defensive instead of dealing with service problem & .43 \\
& Competition & .56 \\
\hline
\end{tabular}

\section{Specification of the structural and measurement models}

Based on the hypothesised relationships in Figure 2, three equations have been constructed linking the exogenous constructs to the endogenous constructs as provided in Table 3. Table 3 also indicates how the linear regression equations have been used in specifying the structural and measurement model.

The structural model in this study consists of 3 endogenous and 12 exogenous variables. The parameters $\beta_{1}, \beta_{2}, \beta_{3}, \beta_{4} \ldots \beta_{14}$ are the regression coefficients to be estimated. Error terms represent the error in measuring the conceptual variables (Maruyama, 1998). The error terms were fixed at unity to allow for the estimation of regression weights. 
Table 2 Internal consistency and correlation matrix

\begin{tabular}{|c|c|c|c|c|c|c|c|c|c|c|c|c|c|c|c|c|}
\hline & $\alpha$ & 1 & 2 & 3 & 4 & 5 & 6 & 7 & 8 & 9 & 10 & 11 & 12 & 13 & 14 & 15 \\
\hline 1. SEF & .89 & 1.00 & & & & & & & & & & & & & & \\
\hline 2. PRICE & .84 & .32 & 1.00 & & & & & & & & & & & & & \\
\hline 3. PUSHY & .82 & .67 & .31 & 1.00 & & & & & & & & & & & & \\
\hline 4. ETHICS & .78 & .42 & .28 & .56 & 1.00 & & & & & & & & & & & \\
\hline 5. PSQ & .72 & .51 & .56 & .47 & .33 & 1.00 & & & & & & & & & & \\
\hline 6. UNREL & .77 & .55 & .25 & .59 & .28 & .51 & 1.00 & & & & & & & & & \\
\hline 7. RISK & .71 & .32 & .32 & .44 & .34 & .41 & .41 & 1.00 & & & & & & & & \\
\hline 8. QUIT & .74 & -.07 & .12 & .12 & .18 & -.09 & .14 & .14 & 1.00 & & & & & & & \\
\hline 9. INC & .70 & .16 & .18 & .15 & .09 & .23 & .16 & .12 & .31 & 1.00 & & & & & & \\
\hline 10. REB & .77 & .41 & .53 & .41 & .33 & .57 & .38 & .28 & .09 & .22 & 1.00 & & & & & \\
\hline 11. RTSF & .70 & .42 & .23 & .41 & .42 & .42 & .27 & .27 & .17 & -.10 & .30 & 1.00 & & & & \\
\hline 12. COMP & .70 & .26 & .16 & .26 & .33 & .14 & .25 & .10 & .09 & .33 & .16 & .34 & 1.00 & & & \\
\hline 13. SWITCH & - & .08 & -.09 & .23 & .12 & .11 & .13 & .11 & 17 & .10 & .66 & .15 & .09 & 1.00 & & \\
\hline 14. RELAT & .89 & .22 & 13 & .29 & .11 & .14 & .22 & .31 & .14 & .08 & .05 & .12 & .08 & -.11 & 1.00 & \\
\hline 15. LOYAL & .74 & .21 & .15 & .21 & .20 & .12 & .11 & .11 & .33 & .66 & .23 & .16 & .15 & -.29 & .32 & 1.00 \\
\hline
\end{tabular}


Table 3 Specification of the structural and measurement model

\begin{tabular}{|c|c|}
\hline Switch $=$ & $\begin{array}{l}\beta_{1} \text { sef }+\beta_{2} \text { price }+\beta_{3} \text { pushy }+\beta_{4} \text { ethics }+\beta_{5} \text { psq }+\beta_{6} \text { unrel }+\beta_{7} \text { risk }+ \\
\beta_{8} \text { quit }+\beta_{9 \text { inc }}+\beta_{10} \text { reb }+\beta_{11} \text { rstf }+\beta_{12} \text { comp }+\xi_{1}\end{array}$ \\
\hline Relat $=$ & $\beta_{13}$ Switch $+\xi_{2}$ \\
\hline Loyal = & $\beta_{14}$ relat $+\beta_{15}$ switch $+\xi_{3}$ \\
\hline
\end{tabular}

Figure 2 A path diagram for the switching behaviour model

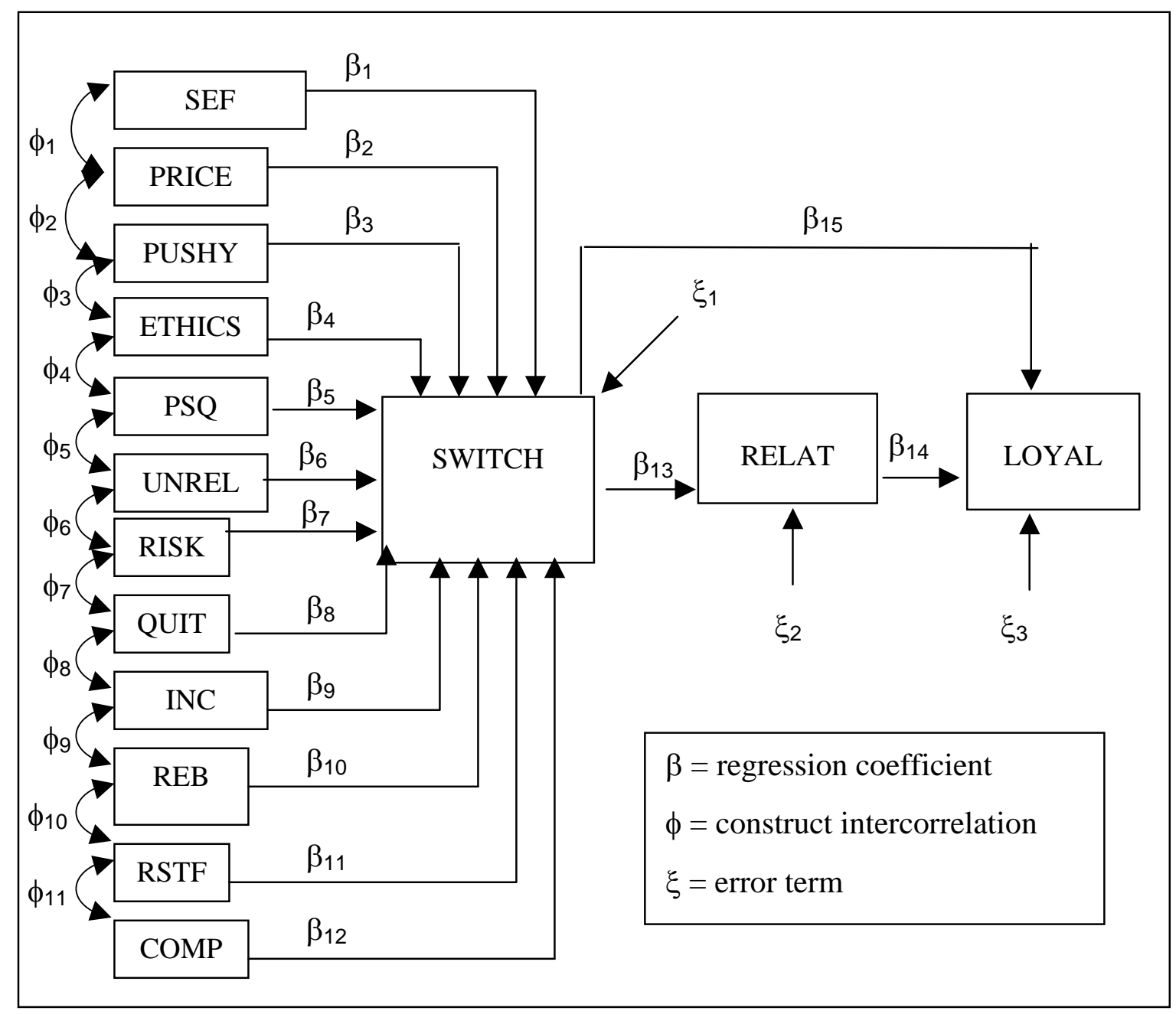

\section{Model estimation}

The maximum likelihood estimates generated by structural equation modeling software (Amos) are outlined in Table 4. Maruyama (1998) suggests that model parsimony can be achieved by eliminating insignificant paths, that is paths with critical ratio less than 2. Table 4 shows that regression coefficients for poor service quality-switching behaviour link were lower than standard error, 
resulting in a critical ratio less than 2 . This led to a decision to eliminate the path. The inconvenience-switching behaviour link was also insignificant as illustrated in Table 4.

Service encounter failure was found to be most predictive of switching behaviour $\left(\beta_{1}=.190\right)$, followed by pushiness $\left(\beta_{3}=.179\right)$ and the unreliability $\left(\beta_{6}\right.$ $=.163$ ) of sales people. Pricing had the least predictive power of the switching behaviour, indicating that direct sales customers are more concerned with the ethical behaviour $\left(\beta_{4}=.128\right)$ of direct sales people, and their responsiveness to service failure than they are with the price. One would have expected the risk associated with purchasing directly sold products to have a bigger impact on the switching behaviour as suggested by Kustin and Jones (1995), whereas this was not the case.

\section{Table 4 Parameter estimates for the revised structural model}

\begin{tabular}{|l|c|c|c|}
\hline \multicolumn{1}{|c|}{ Path } & Estimates & $\begin{array}{c}\text { Standard } \\
\text { error }\end{array}$ & $\begin{array}{c}\text { Critic I } \\
\text { ratio }\end{array}$ \\
\hline Service encounter failure/switch & $\beta_{1}=.190$ & .093 & 2.10 \\
\hline Price/switch & $\beta_{2}=.079$ & .052 & 1.52 \\
\hline Pushiness/switch & $\beta_{3}=.179$ & .085 & 2.12 \\
\hline Ethics/switch & $\beta_{4}=.128$ & .087 & 1.47 \\
\hline Poor service quality/switch & $\beta_{5}=.003$ & .098 & .030 \\
\hline Unreliability/switch & $\beta_{6}=.163$ & .091 & 1.79 \\
\hline Risk/switch & $\beta_{7}=.082$ & .049 & 1.70 \\
\hline Quitting behaviour/switch & $\beta_{8}=.094$ & .044 & 1.57 \\
\hline Inconvenience/switch & $\beta_{9}=.006$ & .046 & .134 \\
\hline Rebate error/switch & $\beta_{10}=.120$ & .071 & 1.69 \\
\hline $\begin{array}{l}\text { Response to core service } \\
\text { failure/switch }\end{array}$ & $\beta_{11}=.105$ & .056 & 1.87 \\
\hline Competition/switch & & & \\
\hline Switch/interpersonal relations & $\beta_{12}=.089$ & .055 & 1.62 \\
\hline Interpersonal relations/loyalty & $\beta_{13}=-.14$ & .065 & 2.15 \\
\hline Switch/loyalty & $\beta_{14}=.309$ & .085 & 3.63 \\
\hline
\end{tabular}

Table 4 also reveals that interpersonal relations have the highest predictive power of the loyalty of direct sales customers $\left(\beta_{14}=.309\right)$ compared to switching behaviour $\left(\beta_{15}=-.145\right)$. The direction of the switching behaviourinterpersonal relations, and switching behaviour-loyalty relations was negative as hypothesised. This suggests that there is a negative correlation between switching behaviour and good interpersonal relationships which implies that the 
more the customers exhibit switching behaviour, the weaker the relationship between the seller and the buyer. Furthermore, a negative correlation between switching behaviour and loyalty would seem to suggest that the more meaningful the interpersonal relationship, the greater the demonstration of loyalty is likely to be; and the less likely it is that the consumer will switch to another supplier.

\section{Figure 3 Revised switching behaviour model}

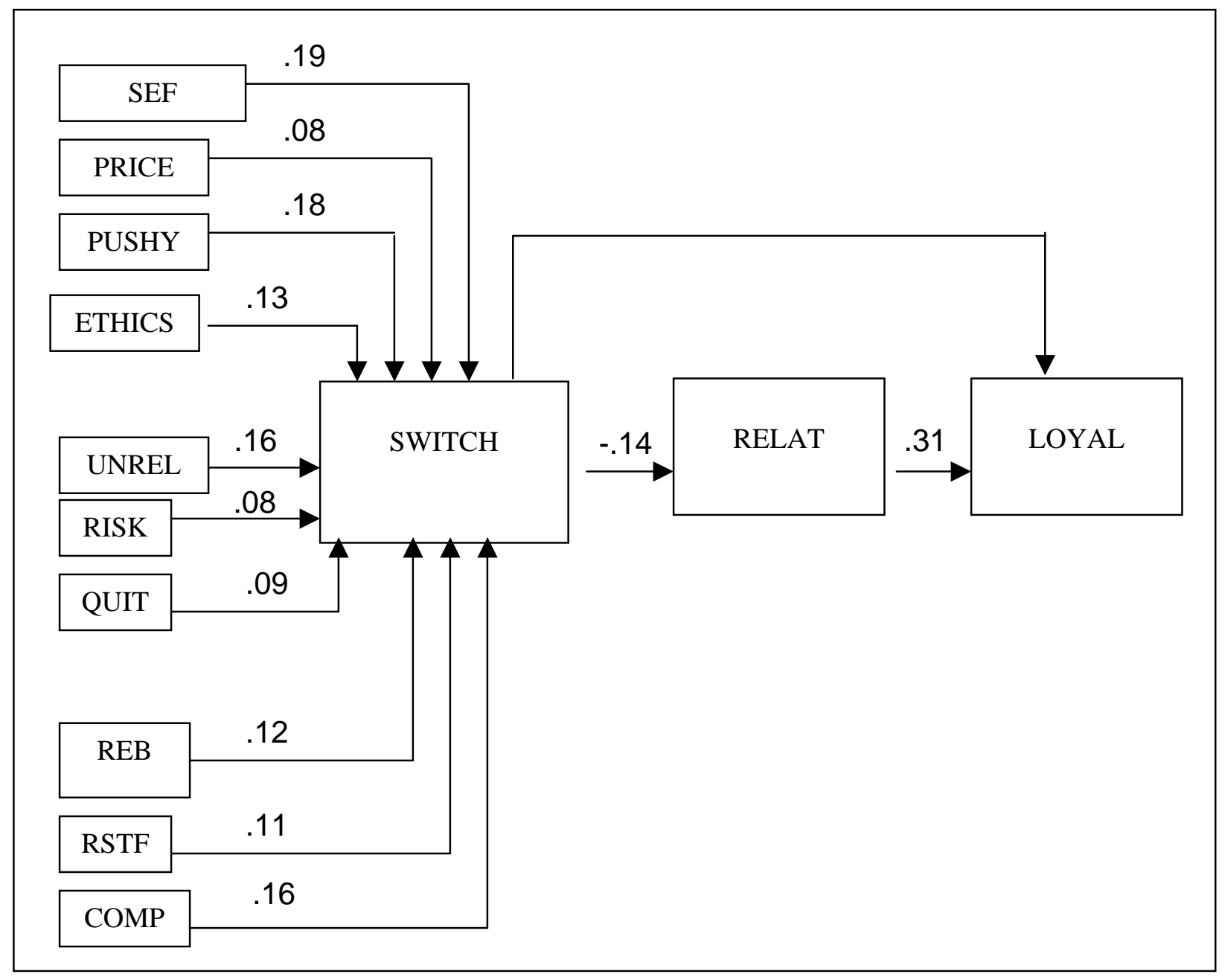

When evaluating the indicator loadings for statistical significance, the $t$ values associated with each variable have to exceed the critical value of 1.96 at 0.05 significance level. Table 4 illustrates that service encounter failure, pushiness, switching behaviour and interpersonal relations were the only variables whose $t$ values exceeded the critical values for the 0.05 significance level (1.96). However, Bentler (1980) argues that model parameters whose estimates are small compared to their standard errors are insignificant and should be eliminated when revising the model. This procedure was used by Mackenzie et al. (1998), in their research, and is adopted in revising the model in this study. The statistical theory for this method is known as the Wald test (Bentler \& 
Chou, 1987, Bentler, 1990). Based on Bentler and Chou's (1987) argument that, when the Wald test is used, there is no need for a number of alternative models to be tested, one general model which was later modified was estimated in this study.

Using Bentler's argument and based on the Wald statistical theory, it was found necessary to retain the following relationships in the model even though the $t$ values associated with predictor variables were less than the critical values for the 5 per cent significance level:

1 price/switch

2 ethics/switch

3 unreliability switch

4 risk/switch

5 quit/switch

6 rebate error switch

7 response to core service failure/switch

8 competition/switch

9 switch/loyalty

This was done because the model had a better fit when the nine relationships were included in the model.

Figure 3 illustrates the revised model after the insignificant paths were removed. As anticipated, the variable interpersonal relations is an intervening variable in the switching behaviour-loyalty link. Figure 3 also shows that service encounter failure is the most predictive factor driving the quitting behaviour of direct sales people, followed by pushiness and unreliability.

\section{Table 5 Assessment of goodness-of-fit measures}

\begin{tabular}{|l|c|c|}
\hline Goodness-of-fit measure (N= 200) & $\begin{array}{c}\text { Proposed } \\
\text { model }\end{array}$ & $\begin{array}{c}\text { Revised } \\
\text { model }\end{array}$ \\
\hline Chi-square $\left(\chi^{2}\right)$ & 130.22 & 90.04 \\
\hline Degree of freedom (df) & 95 & 25 \\
\hline Significance level & .48 & .48 \\
\hline Goodness-of-fit Index (GFI) & .788 & .965 \\
\hline Adjusted-goodness-of-fit index (AGFI) & .676 & .887 \\
\hline Normed fit index (NFI) & .820 & .905 \\
\hline $\begin{array}{l}\text { Root mean square error of approximation } \\
\text { (RMSEA) }\end{array}$ & .092 & .083 \\
\hline
\end{tabular}


Fitting the revised model resulted in an adequate fit $\left(\chi^{2}=90.04, \mathrm{df}=25, \mathrm{p}=\right.$ 0.48 ) in accordance with the Goodness-of-Fit Index (GFI) of .965, and Adjusted-Goodness-of-Fit Index (AGFI) of .887. The Normed Fit Index (NFI) of the revised model was found to be .905 , and the Root Mean Square Error of Approximation (RMSEA) .083, verifying an acceptable fit of data to the hypothesised model (Bentler, 1990). In comparing the results of confirmatory factor analysis and exploratory factor analysis, it can be observed that ten instead of twelve factors drive the switching behaviour of direct sales people.

\section{DISCUSSION AND IMPLICATIONS FOR MANAGEMENT}

This study provides a broader perspective with regard to the switching behaviour of direct sales customers. The results confirm an earlier notion by Srnivasan (1996) that low switching behaviour depends upon the propensity of customers to display loyalty. The findings emphasize that, as the inclination to switch suppliers increases, the loyalty levels decrease, suggesting that in order to improve loyalty among customers, direct sales managers might have to concentrate on reducing those factors that cause customers to switch suppliers. The question is how this can be achieved. In response to this challenge this study has identified ten variables that are most likely to cause customers to switch suppliers: (1) service encounter failure, (2) pushiness of direct sales people, (3) unreliability of direct sales people, (4) the ethics of direct sales people, (5) rebate errors, (6) responsiveness to service failure, (7) the quitting behaviour of sales people, (8) competitors, (9) risk, and (10) pricing of direct sales products. According to Wald's test these ten variables impact significantly on the switching behaviour as illustrated in Table 4 .

As illustrated on Table 1 and Figure 4, both exploratory factor analysis and structural equation modeling have provided compelling evidence that service encounter failure exercises a greater influence on switching behaviour than other variables. The nature of service encounters in the direct selling industry often begins with a direct seller and a customer, or when customers purchase products from direct selling service centres. As this study has shown, the attitude of the service personnel, their helpfulness and willingness to accommodate requests impacts on decisions to switch suppliers. Personnel in the service centres as well as direct sellers require skills and the right type of personality to handle service encounters effectively. The relevant skills and an appropriate personality coupled with training and motivation are essential in keeping direct selling customers satisfied.

As revealed in the findings in a number of studies (Peterson, Albaum \& Ridgway, 1989; Kustin \& Jones, 1994; Sargeant \& Msweli-Mbanga, 1999), 
pushiness and the unreliability of direct sales people are major factors in predicting switching behaviour in customers. Given the invisible nature of direct selling, it becomes important for direct sales people to maintain access to their customers. If not, they lose their customers and their credibility. To counteract the unreliability of sales people, direct selling firms are now providing customers with additional avenues for accessing products. There are trends towards the establishment of direct sales retail outlets and kiosks in shopping malls. For example, Unilever Networks, and Avon, both have retail outlets at The Workshop - a shopping mall in Durban. House of Health has retail stores in La Lucia Mall, Windermere Centre, and Sanlam Centre in Pinetown. Some firms give customers the option of ordering directly via an 0800 number, by fax, or electronically. This move has provided leverage for direct selling and opened the way for improved performance.

The pricing of direct sales products was found to have the least predictive power of the switching behaviour of customers compared to other factors. The reason for this is unclear. It is possible that direct sales customers place more emphasis on personalised service and a relationship with the seller than on price. The strong link between interpersonal relations and loyalty in this study is consistent with the findings of Frenzen and Davis (1990). This finding confirms that in the direct selling context, interpersonal relations moderate the switching behaviour-loyalty link. The implications of these findings are that, direct sales people need to develop relationship building skills not only to ensure the loyalty of their customers, and thereby to retain existing customers, but also in order to .attract new customers.

\section{LIMITATIONS AND FUTURE RESEARCH}

The findings of this study are limited in their generalizability, firstly, because respondents were drawn from a non-probability sample. Secondly, the sample size of 200 provides a low case-to-variable ratio, given that exploratory factor analysis was undertaken with 68 items. Replication is needed with a bigger sample size to increase the statistical power of the findings. A measurement limitation in the research also need to be mentioned. Switching behaviour was measured by a single item, whereas multiple items would have been preferable. It would be valuable to reproduce this study with a psychometrically valid measure of the switching behaviour variable.

Future research needs to examine whether there is a higher incidence of switching from one direct selling firm to another or from a direct selling firm to a conventional retail supplier. It would also prove to be useful to examine the extent to which customers interact with service personnel in distribution outlets 
compared to the extent to which they interact with the direct seller. Based on the premise that a direct seller is psychologically closer to the customer than direct sales service personnel, one would expect service encounter with a direct seller to exert more influence on switching than service encounter with service personnel in retail outlets. Further research is needed to gain perspective on other dimensions of the equation.

While structural equation modeling confirms a specified model, with path specifications based on theoretical rationale, the technique does not confirm that it is the only acceptable model. Further research is required to evaluate the model estimated in this study using either competing model strategy or nested model strategy.

Although this study has found that switching behaviour and interpersonal relations are the antecedents of loyalty, it is important to remember that loyalty is a consequence of a number of variables. This presents research opportunities to identify additional antecedents of loyalty within the direct selling context.

\section{REFERENCES}

1 ANDERSON, J.C. \& GERBING, D.W. (1988) "Structural equation modelling in practice: a review and recommended two-step approach", Psychological Bulletin, 103(3): 411-23.

2 BAGOZZI, R.P. (1980) "Performance and satisfaction in an industrial sales force: An examination of their antecedents and simultaneity", Journal of Marketing, 44 (Spring): 65-77.

3 BASS, F.M. (1974) "The theory of stochastic preference and brand switching”, Journal of Marketing_Research, 11 (February): 1-20.

4 BENTLER, P.M. (1980) "Multivariate analysis with latent variables: causal modelling”, Annual Review of Psychology, 31: 419-56.

5 BENTLER, P.M. (1990) "Comparative fit indexes in structural models", Psychological Bulletin, 107 (2): 238-46.

6 BENTLER, P.M. \& CHOU, C. (1987) "Practical issues in structural modelling”, Sociological Methods and Research, 16 (Aug): 78-117.

7 BERRY, R. (1997) Direct Selling - From Door to Door to Network Marketing, Butterworth Heinemann: Oxford.

8 BLOCH, B. (1996) “Multilevel marketing: What's the catch?” Journal of Consumer Marketing, 13(4): 18-26.

9 BRYMAN, A. \& CRAMER, D. (1994) Quantitative Data Analysis for Social Scientists, London: Routlidge.

10 CAPRARO, A.J., BRONIARCZYK, S. \& SRIVASTAVA, R.J. (2003) "Factors Influencing the Likelihood of Customer Defection: The Role of 
Consumer Knowledge”, Journal of the Academy of Marketing Science, 31(2): 164-75.

11 CARPENTER, G.S. \& LEHMANN, D.R. (1985) “A model of marketing mix, brand switching, and competition” Journal of Marketing Research, 22 (3): 318-29.

12 CHANCE, W.A. \& FRENCH, N.D. (1972) "An exploratory investigation of brand switching”, Journal of Marketing Research, IX (May): 226-29.

13 CHURCHILL, G.A. (1996) Basic Marketing Research, Orlando: Dryden Press.

14 CHURCHILL, G.A., FORD, N.M. \& WALKER, O.C. (1974) "Measuring the job satisfaction of industrial salesmen", Journal of Marketing Research, X1: 254-60.

15 CLOTHIER, P. (1994) Multi-level Marketing: A Practical Guide To Successful Network Marketing, Kogan Page: London.

16 DE RUYTER, K. (1998) "On the relationship between perceived service quality, service loyalty and switching costs”, International Journal of Service Industry Management, 9 (5): 436-53.

17 FRENZEN, J.K. \& DAVIS, H.L. (1990) "Purchasing behaviour in embedded markets”, Journal of Consumer Research, 17 (June): 1-12.

18 GANESH, J., ARNOLD, M.J., \& REYNOLDS, K.E. (2000) "Understanding the customer base of service providers: An examination of the differences between switchers and stayers”, Journal of Marketing, 64(3): 65-82.

19 GUADAGNI, P. \& LITTLE, J.D. (1983) "A logit model of brand choice calibrated on scanner data”, Marketing Science, 2 (Summer): 203-38.

20 GUPTA, S. (1988) "The impact of sales promotion on when, what and how much to buy”, Journal of Marketing Research, 25 (November): 34255.

21 HAIR, J.F. (Jr.), ANDERSON, R.E., TATHAM, R. L. \& BLACK, W. C. (1998) Multivariate data analysis $\left(5^{\text {th }}\right.$ ed.) New Jersey: Prentice Hall.

22 HOM, P.W. \& KINICKI, A.J. (2001) "Toward a greater understanding of how dissatisfaction drives employee turnover”, Academy of Management Journal, 44 (5): 975-87.

23 JONES, M.A., MOTHERSBAUGH, D.L. \& BEATTY, S.E. (2000) "Switching barriers and repurchase intentions in services" Journal of Retailing, 59: 71-82.

24 JÖRESKOG, K.G. \& SORBOM, D. (1996) LISREL 8: User's Reference Guide, Scientific Software International: Chicago.

25 KEAVENEY, S.M. (1995) "Customer switching behaviour in service industries: An exploratory study”, Journal of Marketing, 59: 71-82.

26 KUEHN, A.A. (1962) "Consumer brand choice - A learning process", Journal of Advertising Research, 2 (December): 10-17. 
27 KUSTIN, R.A. \& JONES, R.A. (1995) "Research note: A study of direct selling perceptions in Australia", International Marketing Review, 12(6): 60-7.

28 LAMBERT, D.M., SHARMA, A., \& LEVY, M. (1997) "What information can relationship marketers obtain from customer evaluations of salespeople”, Industrial Marketing Management, 26: 177-87.

29 LEE, M. \& CUNNINGHAM, L.F. (2001) "A cost/benefit approach to understanding service loyalty”, Journal of Services Marketing, 12(3): 113-30.

30 MACKENZIE, S.B., PODSAKOFF, P.M. \& AHEARNE, M. (1998) "Some possible antecedents and consequences of in-role and extra-role salesperson performance”, Journal of Marketing,. 62 (July): 224-47.

31 MARUYAMA G.M. (1998) Basics of Structural Equation Modelling, Sage Publications: London.

32 MITTAL, B. \& LASSAR, W.M. (1998) "Why do customers switch? The dynamics of satisfaction versus loyalty”, Journal of Services Marketing, 12(3): 177-94.

33 MORRISON, D.G. (1966) “Testing brand switching models”, Journal of Marketing Research, 3 (November): 401-9.

34 MSWELI-MBANGA, P. (2001) "Modelling distributor performance in network marketing organisations" South African Journal of Business Management, 32 (3): 33-40.

35 NORUŠIS M. J. (1994) SPSS Professional Statistics 6.1, Chicago: SPSS Inc.

36 NUNNALLY J.C. \& BERNSTEIN I.R. (1994) Psychometrics Theory, ( $3^{\text {rd }}$ ed.) Mc Graw-Hill Series in Psychology: New York.

37 PARASURAMAN, A., ZEITHMAL, V.A. \& BERRY, L.L. (1988) "SERVEQUAL: A multiple-item scale for measuring consumer perceptions of service quality”, Journal of Retailing, 64 (1): 12-40.

38 PETERSON, R.A., ALBAUM, G. \& RIDGWAY, N.M. (1989) "Consumers who buy from direct sales companies" Journal of Retailing, 65 (2): 273-86.

39 PETERSON, R.A. \& WOTRUBA, T.R. (1996) "What is direct selling? Definition, perspectives and research agenda” Journal of Personal Selling and Sales Management, XVI (4): 1-16.

40 RYAN, E. 2002 "Creating jobs and making fortunes for a few”, Sunday Times Business Times, 16 (June): 18.

41 SAGER, J.K. \& MENON, A. (1994) "The of behavioural intentions in turnover of salespeople”, Journal Business of Research, 29: 179-188.

42 SARGEANT, A. \& MSWELI-MBANGA, P. (1999) "Network marketing in South Africa: Just what is the perception?” Journal of the International Consumer Marketing, 11(3): 51-66. 
43 SIROHI, N. \& MC LAUGHLIN, E.W. (1998) "A model of consumer perceptions and store loyalty intentions for a supermarket retailer", Journal of Retailing, 74 (2): 223-46.

44 SRNIVASAN, M. (1996) "New insights into switching behaviour" Marketing Research, 8(3): 26-33.

45 TYAGI, P.K. \& WOTRUBA, T.R. (1993) "An exploratory study of reverse causality relationships among salesforce turnover variables”, Journal of the Academy of Marketing Science, 21(2): 143-53.

46 World Federation of the Direct Selling Association (2001) Industry Statistics, www.dsasa.co.za. 